Bergersen, F. J. (1953). J. gen. Microbiol. 9, 353-356.

\title{
Cytological Changes induced in Bacterium coli by Chloramphenicol
}

\author{
BY F. J. BERGERSEN \\ Department of Bacteriology, University of Otago Medical \\ School, Dunedin, New Zealand
}

SUMMARY: Under certain conditions chloramphenicol influences the growth and division of Bacterium coli so that abnormal forms are produced. These include long and sometimes pointed filaments and branched forms which seem to arise from organisms with abnormal growing points. Changes in morphology are preceded by changes in nuclear structure. The processes described occur only within critical limits of concentration of the antibiotic, and these limits vary when different strains of Bacterium coli are used.

It was found by Knaysi (1930) that basophilic granules occurred in the cell periphery of Bacillus subtilis at the site of development of transverse membranes. Similar granules have also been shown by the author in B. megaterium (Bergersen, 1953). Bisset (1951) described regions of active growth in Gram-negative bacilli, in which the structures of the cell envelope are laid down. These show as deeply stained areas with basic dyes and have been termed 'growing points'. Fleming, Voureka, Kramer \& Hughes (1950) demonstrated cytological changes induced in Proteus vulgaris by penicillin. More recently, Pulvertaft (1952) described characteristic changes in Bacterium coli grown on media containing chloramphenicol. Evidence that chloramphenicol affects the nuclear material was presented by Voureka (1952), who showed heritable changes produced in a staphylococcus after treatment with the antibiotic. The present work contains additional evidence that chloramphenicol acts on nuclear processes, and demonstrates the possibility that abnormal growing points have a role in the production of aberrant forms.

\section{MATERIALS AND METHODS}

The effects of chloramphenicol were tested against eight freshly isolated faecal strains of Bact. coli. These were grown in $\mathbf{5}$ ml. amounts of nutrient broth in $20 \mathrm{ml}$. screw-cap bottles. Centrifuged deposits from cultures of various ages were smeared on coverslips, fixed in osmic acid vapour and dried in air at room temperature. Cytoplasmic structures were examined, using the $\mathrm{HCl}+\mathrm{Giemsa}$ method of Robinow (1942). Cell walls were stained by his tannic acid-crystal violet method and by $0.5 \%$ Victoria blue $4 \mathbf{R}$ (Gurr). All preparations were examined in water mounts.

Chloramphenicol was added to cultures in concentrations which slightly inhibited growth after $12 \mathrm{hr}$. incubation at $37^{\circ}$; for most of the strains used this concentration was $2.5 \mu \mathrm{g}$. $/ \mathrm{ml}$. Two strains were completely inhibited by this concentration, and $1.0 \mu \mathrm{g} . / \mathrm{ml}$. gave the characteristic morphological changes. In a particularly resistant strain these changes were produced with $25 \mu \mathrm{g} . / \mathrm{ml}$. 


\section{OBSERVATIONS}

Untreated cultures contained typical organisms $2-4 \mu$. long and $0.5 \mu$. in diameter. Cell membranes were stained a darker pink than the cytoplasm by the HCl-Giemsa method, and growing points appeared as granules at the poles and at the transverse septa of dividing cells. The nuclear bodies stained a deep blue (Pl. 1, fig. 1). Seven minutes hydrolysis in $\mathrm{N}-\mathrm{HCl}$ was sufficient to produce satisfactorily stained preparations from untreated cultures, but longer periods, in proportion to the time in contact with the antibiotic, were required for those treated with chloramphenicol.

After treatment for $\mathbf{8 ~ h r}$. the organisms were slightly larger than those of the control cultures, and their nuclear material was arranged in irregular bars which were often asymmetrically distributed in the cells. There appeared to be little or no cell division in these cultures and only polar growing points were seen (Pl. 1, fig. 2).

Organisms treated for $16 \mathrm{hr}$. were further enlarged and the polar growing points were prominent and well stained. Approximately one organism in twenty had additional granules which often protruded from the cell outlines and which were apparently identical to the granules of the polar growing points. These granules were usually in the lateral part of the cell membrane towards one pole of the cell. Nuclear bodies were enlarged and in pairs (Pl. 1, figs. 8-6).

After 22-28 hr. incubation the organisms were enormously enlarged, difficult to hydrolyse, and, in many cases, sharply pointed. In these preparations approximately one organism in twenty appeared to be branched. When cell-wall stains were used these giant forms were seen to have few transverse septa and the branched forms possessed continuous cell walls (Pl. 1, figs. 7-10). After further incubation the branched forms were larger and stained poorly, having the appearance of dead cells (Pl. 1, fig. 11).

A $16 \mathrm{hr}$. culture containing cells with abnormal growing points was centrifuged and resuspended in several changes of broth to remove the antibiotic. After $12 \mathrm{hr}$. incubation, $\mathrm{HCl}+$ Giemsa preparations showed that the resulting culture was returning to normal (Pl. 1, fig. 12).

\section{DISCUSSION}

From this work it seems that chloramphenicol exerts an effect on nuclear division in Bact. coli. Abnormal appearances of the nuclear material are among the first cytological changes observed. Extra granules which resemble growing points in their staining reactions then make their appearance in some cells and polar growing points become prominent in all of them. Cell proliferation in these regions may result in the branched forms and in the long, pointed organisms, as illustrated in the diagrams, Figs. 1-4. Up to a certain stage these changes seem to be reversible, as removal of the antibiotic results in normal cultures, while further incubation with the antibiotic results in loss of viability.

Pulvertaft's description of the giant cells obtained from Bact. coli treated with chloramphenicol corresponds fairly closely with this work. His failure to 
observe branching may have been due to the use of different antibiotic concentrations, to the use of solid media, to the different duration of the experiments, or to combinations of these factors.
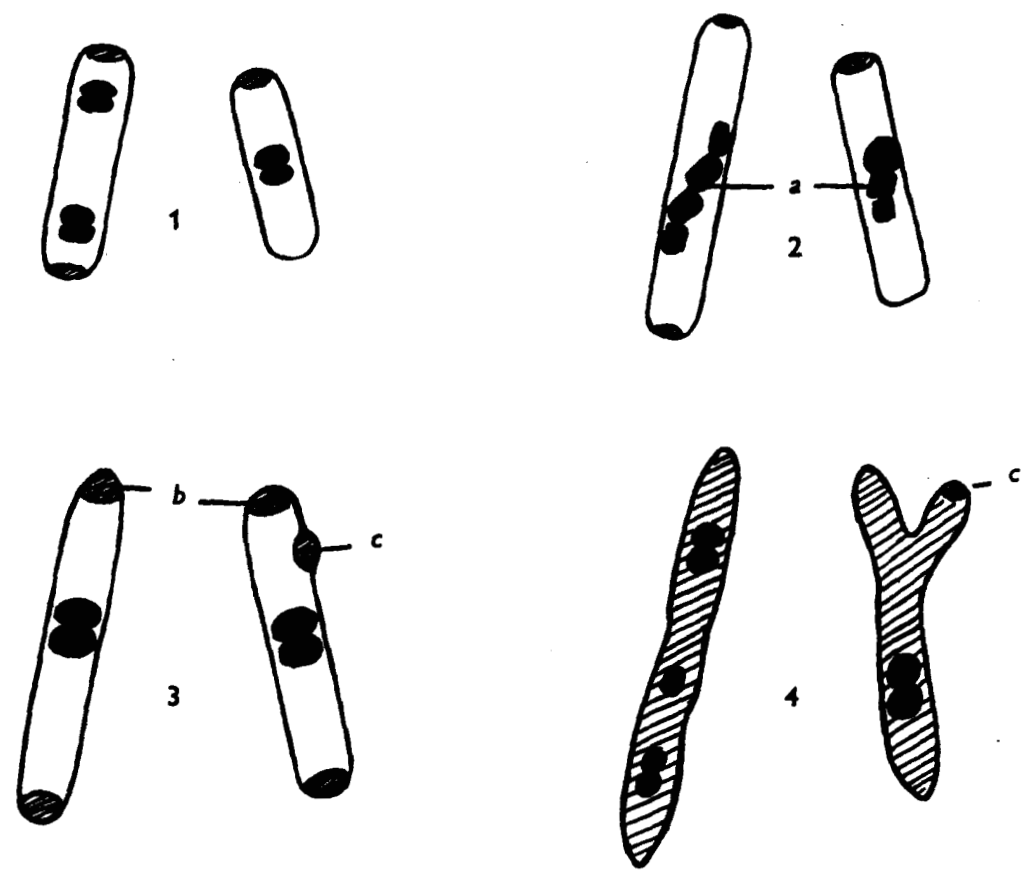

Figs. 1-4. Diagrams of the changes in a strain of Bact. coli grown in the presence of $2 \cdot 5 \mu \mathrm{g}$. chloramphenicol/ml. Fig. 1. Typical untreated cells. Fig. 2. After $8 \mathrm{hr}$. treatment showing enlargement and nuclear changes $(a)$. Fig. 3. After $16 \mathrm{hr}$. treatment showing prominent polar growing points $(b)$ and an extra growing point $(c)$. Fig. 4. Giant forms after $22 \mathrm{hr}$. treatment- the cell envelopes are dense and the cytoplasm basophilic. Some show branching as at $(c)$.

Branching was only seen in some of the treated organisms and this fraction seemed to correspond to the proportion of cells showing extra growing points at an earlier stage. These extra growing points may be part of the normal process of cell division, but this cannot proceed in the normal way because of the affected nucleus. Asymmetrical growth may result, and in some cases this may lead to outgrowths of the cell to give a branched form.

\section{REFERENCES}

Bergersen, F. J. (1953). A probable growth cycle in Bacillus megaterium. J. gen. Microbiol. 9, 26.

BISSET, K. A. (1951). The development of the surface structures in dividing bacteria. J. gen. Microbiol. 5, 155.

Fleming, A., Voureka, A., Kramer, I. R. H. \& Hughes, W. H. (1950). The morphology and motility of Proteus vulgaris and other organisms cultured in the presence of penicillin. J. gen. Microbiol. 4, 257.

KNAYsI, G. (1930). Cell structure and cell division of B. subtilis. J. Bact. 19, 113. 
Pulvertaft, R. J. V. (1952). The effect of antibiotics on growing cultures of Bacterium coli. J. Path. Bact. 64, 75.

Robinow, C. F. (1942). A study of the nuclear apparatus of bacteria. Proc. Roy. Soc. B, 130, 299.

Voureka, A. (1952). Induced variations in a penicillin-resistant staphylococcus. J. gen. Microbiol. 6, 352.

\section{EXPLANATION OF PLATE}

Fig. 1. Cells from an untreated $8 \mathrm{hr}$. broth culture of Bact. coli showing paired nuclear bodies and polar growing points. $\mathrm{HCl}+$ Giemsa, $\times 2000$.

Fig. 2. Cells from an $8 \mathrm{hr}$. culture treated with $2 \cdot 5 \mu \mathrm{g}$. chloramphenicol $/ \mathrm{ml}$. $\mathrm{HCl}+$ Giemsa, $\times 2000$.

Figs. 3, 4. Cells from a $16 \mathrm{hr}$. treated culture showing prominent polar growing points. $\mathrm{HCl}+$ Giemsa, $\times \mathbf{3 0 0 0}$.

Figs. 5, 6. Cells from a $16 \mathrm{hr}$. treated culture showing polar and sub-polar extra growing points. HCl + Giemsa, $\times \mathbf{8 0 0 0}$.

Fig. 7. A branched organism from a $22 \mathrm{hr}$. treated culture. Giemsa, $\times 3000$.

Figs. 8, 9. Branching organisms stained to show the cell wall. Tannic acid-crystal violet, $\times \mathbf{3 0 0 0}$.

Fig. 10. Long pointed forms from a $22 \mathrm{hr}$. treated culture. $\mathrm{HCl}+\mathrm{Giemsa}, \times 3000$.

Fig. 11. A branched form from a $36 \mathrm{hr}$. treated culture. $\mathrm{HCl}+$ Giemsa, $\times 3000$.

Fig. 12. Cells from a $16 \mathrm{hr}$. treated culture washed free of antibiotic. Normal morphology. $\mathrm{HCl}+$ Giemsa, $\times \mathbf{3 0 0 0}$. 
Journal of General Microbiology, Vol. 9, No. 3

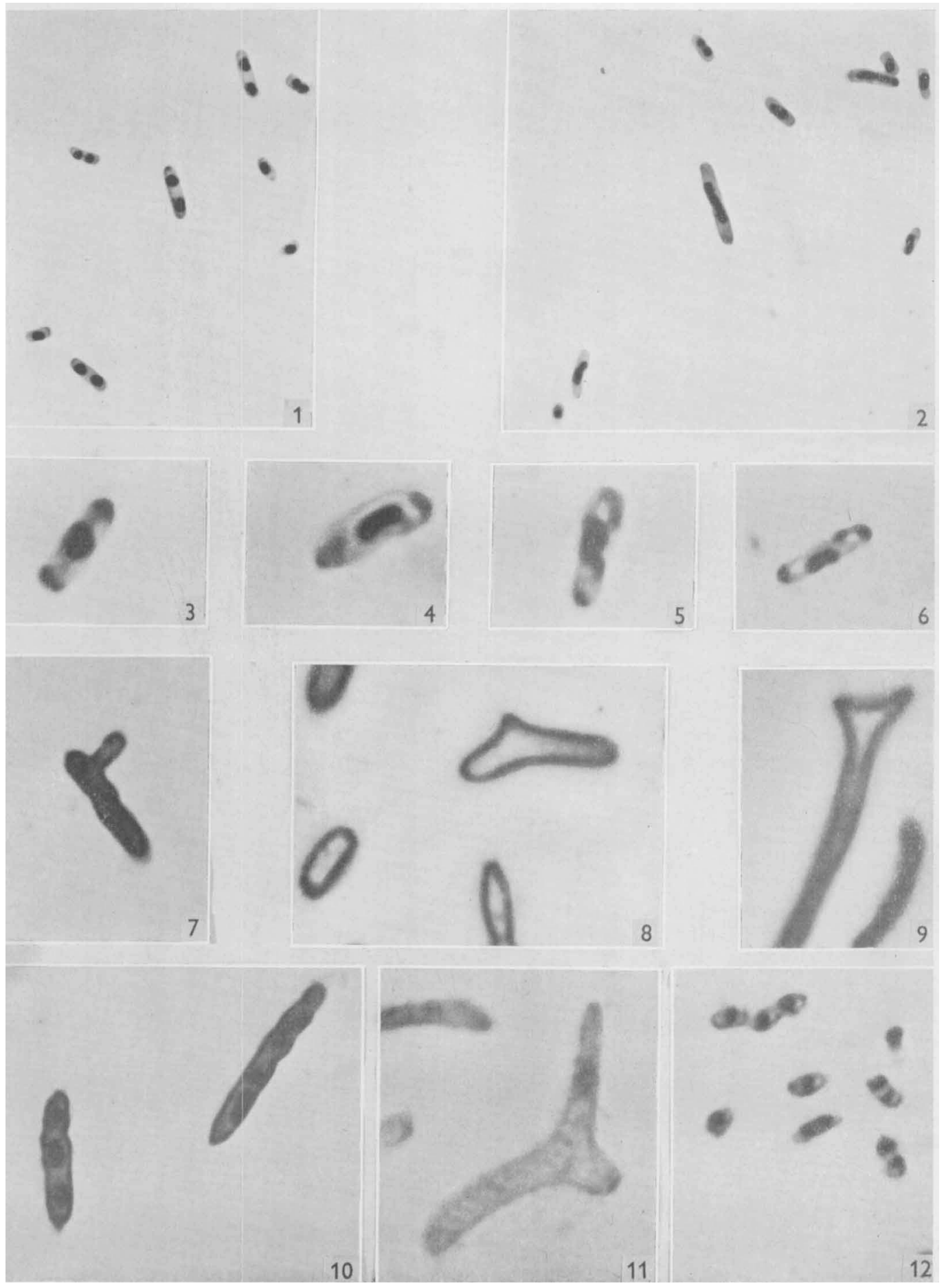

F. J. Bergersen-Cytological changes in Bacterium coli. Plate 1 